Témoigner Témoigner. Entre histoire et mémoire

Getuigen Revue pluridisciplinaire de la Fondation Auschwitz

118 | 2014

Au nom des victimes. Dictature et terreur d'État en Argentine, Chili et Uruguay

\title{
Agenda in het Nederlands en het Engels
}

Agenda in Dutch en English

Agenda en néerlandais et en anglais

\section{(2) OpenEdition}

\section{Journals}

Édition électronique

URL : http://journals.openedition.org/temoigner/1227

DOI : 10.4000/temoigner. 1227

ISSN : 2506-6390

Éditeur :

Éditions du Centre d'études et de documentation Mémoire d'Auschwitz, Éditions Kimé

Édition imprimée

Date de publication : 1 octobre 2014

Pagination : 8-11

ISBN : 978-2-84174-674-3

ISSN : 2031-4183

Référence électronique

«Agenda in het Nederlands en het Engels », Témoigner. Entre histoire et mémoire [Online], 118 | 2014,

Online op 01 octobre 2015, geraadpleegd op 10 décembre 2020. URL : http://journals.openedition.org/ temoigner/1227; DOI : https://doi.org/10.4000/temoigner.1227 
TENTOONSTELLING

\section{De helpers van het} Achterhuis

De tijdelijke tentoonstelling 'De helpers van het Achterhuis' in het Anne Frank Huis belicht de belangrijke rol van de mensen die de onderduik mogelijk hebben gemaakt. Ruim twee jaar lang ben gemaakt. Ruin twee jaar lang zorgden zij dag in dag uit voor de velligheid en het welzijn van

$\diamond$ Van 11 april tot 11 oktober 2014

$\triangle$ Anne Frank Huis, Prinsengracht

67, Amsterdam. www.annefrank.org

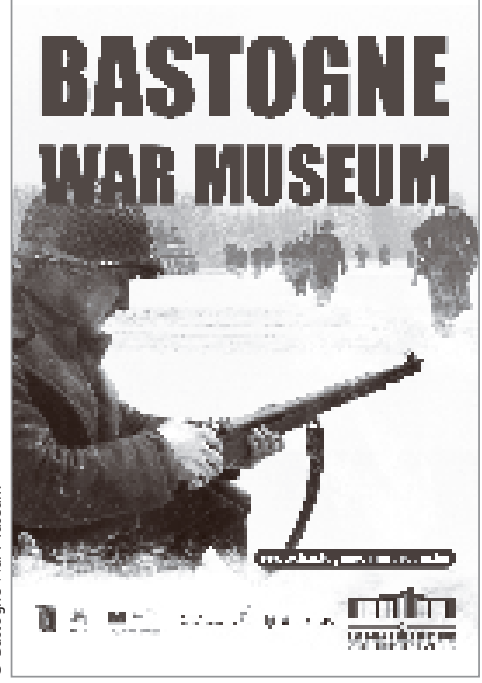

OPENING

\section{Bastogne War Museum}

Vlakbij het beroemde Mardassonmonument ligt het Bastogne War rewijd aan de Tweede Werelder-

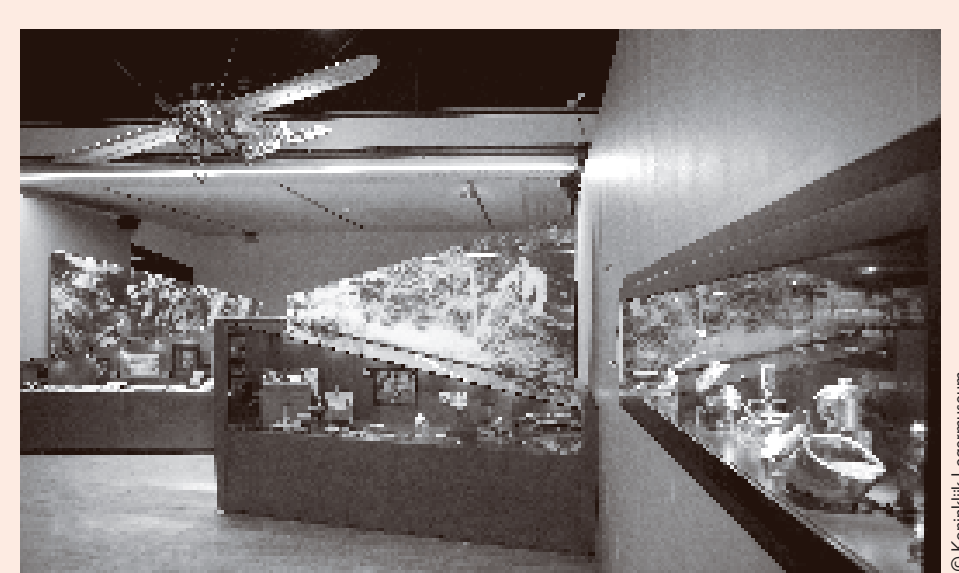

TENTOONSTELLING

14-18, DIT IS ONZE GESCHIEDENIS!

Via authentieke objecten, decors, getuigenissen, multimedia installaties, films en sensoriele ruimtes belicht het Legermuseum het dagelijkse leven tijdens de trachten te redden.

Van 26 februari 2014 tot 26 april 2015.

$\diamond$ Koninklijk Legermuseum, Jubelpark 3, 1000 Brussel. www.expo14-18.be

log in België. Het plaatst de oorzaken, gebeurtenissen en gevolgen van de oorlogin een moderne conals invalshoek. Het nieuwe museumparcours kent een origine uncencol cencon woringen Woringen

$\Leftrightarrow$ Colline du Mardasson 5, 6600

Bastogne. www.bastognewarmuseum.be

TENTOONSTELLING

14-18: Brussel tikt Duits

De Archieven stellen tal van documenten tentoon (postkaarten, die inzicht bieden in het dagelijks leven van de Brusselaar tijdens de bezetting: hoe raakte men aan voedsel, kleding en verwarming? Hoe kon men het hoofd bieden aan de better? Enhoe ingrijpend heeft de Eeste Wereldoorlogonze samin van de twintigte $\Delta$ Van 21 augustus 2014 tot $3 \mathrm{me}$ 2015.

$\diamond$ Archieven van Brussel, Musée de la Ville de Bruxelles, 1000 Brussel.

GEGIDSTE WANDELING

\section{Getekend. De kunstenaar}

Voor kunstenaars aan beide kanten van het front hakt de Eerste
Wereldoorlog als een bottebijl door hun levens en soms nog prille carrières. Het Middelheimmuseum breng deze kunstenaars en hun werk terugonder de aandacht met eententom wandeling door het park. Central $\diamond$ Van 3 mei 2014 tot 11 januari 2015. $\diamond$ Middelheimmuseum, Braempaviljoen, Middelheimlaan 61, 2000 Antwerpen.

EXHIBITION

\section{4-1918.}

The First World War

Taking fourteen salient places as points of departure the exhibition different contexts. Using in dits different ways in which the very were experien a were experienced and helps visitors to understand how dranataffected the people.

$\diamond 29$ May to 30 November 2014.

$\diamond$ Deutsches Historisches Museum,

Unter den Linden 2, 10117 Berlin. www.dhm.de

EXHIBITION

All too human. 20th and $21 s t$ century artists and 21st century
suffering

The museum exhibits a selection of works that look at the suffering inflicted by human beings on other human beings. A set of exhibits has been put together that range from World War by Otto Dix, through

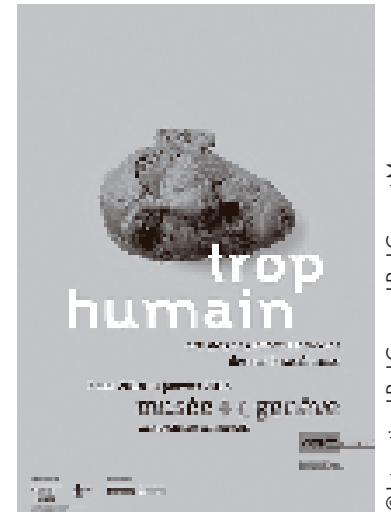

an etching by Pablo Picasso and a painting by Zoran Mušic, to more recentcreative activity, illustrated of Luise Bourgeis (1998). $\diamond 7$ May 2014 to 4 January 2015. $\diamond$ International Red Cross and Red Crescent Museum, Avenue de la Paix 17, 1202 Genève.

EXHIBITION

\section{The First World War in} Jewish Memory

Caught in conflict between belonging and exclusion, the First World point for German-Jewish point for German-Jewish comlar importane in this context are the works of Jewish artists such the worm of Jews arts hardt and Ernst Oppler, who were soldiers at the front. Most of the objects on display in the cabine expects on display in the cabite

3 July to 16 November 2014

$\diamond$ Jewish Museum Berlin,

Lindenstrasse 9-14, 10969 Berlin. www.jmberlin.de
CONFERENCE

\section{4/2014 - The First} Memory Culture

ory Culture

The First World War is regarded s one of the first modern propaganda wars. In all participating culture that is still largely med plored. The Institute for Research on Literature for Young People (Goethe-Universität Fraeple (Goethe-Universitat Frankfurt for children and adolescits 1914 to 1918 and adowents fiom trauma of children.

$\diamond$ 10-12 September 2014

$\diamond$ Holzhausenschlösschen Justinianstrasse 5, 60322 Frankfurt am Main. www.uni-frankfurt.de

EXHIBITION

\section{Truth and Memory: British} Art of the First World War

Truth and Memory will be the largest exhibition and first major War art for almost 100 years and will include work by somears antain's most important artists of the twentieth century Using artwork drawn mainly from IWM's nations drawnmainlyfrom Whs national cossess the immediate impact and enduring innediate inpact and First World War. Brishart of the

$\diamond 19$ July 2014 to 8 March 2015.

$\diamond$ Imperial War Museum, www.iwm.org.uk 
TENTOONSTELLING

\section{Fairplay? Sport en de Eerste} Wereldoorlog

Sport is oorlog, maar verbindt ook mensen. Detentoonstellingbekijkt het sportgebeuren in de context van de Eerste Wereldoorlog, en vertrekt daarbij vanuit persoonlijke verhalen en enkele opmerkelijke objecten uit de collectie van het museum.

$\diamond$ Van 14 juni tot 14 oktober 2014.

$\diamond$ In Flanders Fields, Grote Markt 34 8900 leper.

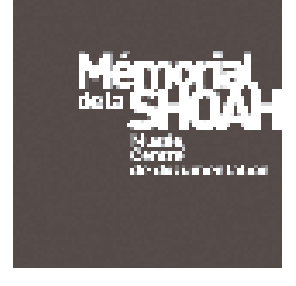

EXHIBITION

\section{Regards sur les ghettos \\ (Views of the ghettos)}

Nearly 500 photographs of the ghettos are on view in the Memohotos showus? Why and bywhon photos show us? Wy and by whom wers they taken? The exhibition

$\diamond$ Until 28 September 2014

$\triangle$ Mémorial de la Shoah,
rue Geoffroy-l'Asnier 17,75004 Paris.

www.regards-ghettos.
memorialdelashoah.org

\section{- OKTOBER}

TENTOONSTELLING

\section{Ver van de Oorlog.} Belgische emigranten in
Amerika tijdens WO I

Het Red Star Line Museum vertelt het verhaal van de Belgisch Anerikanen, die in de oorlogsjaren afgesneden waren van hun familie. Hoe belefden zij de oorfamilie. Hoe beleefden zij de oorlog, ver vande oorlog? Enw welkero Star Line?

$\Leftrightarrow$ Van 26 september 2014 tot 5 april

$\rightarrow$ Red Star Line Museum, Montevideostraat 3, 2000 Antwerpen. www.redstarline.be

\section{EVENEMENT}

\section{De Namenlijst/ \\ ichtfront' 14}

Tijdens het openingsweekend va GoneWest worden de namen va porlogslachtoffers geprojecteer op drie symbolische torens. de (Diksmide (Diksmuide) en het Albert-I monu(Dent (Nieuwpoort). Daarnaast zols die tot stand kwam in het zoals die tot stand kwam in het etting indoktober 8750 partientingeind pantenzullende afstand tussen het teert met fakkels verlicht

$\diamond 17$ oktober 2014.

$\diamond$ www.gonewest.be

\section{EVENEMENT}

\section{Pontonbrug} Ook dit jaar wordt de pontonbrus van 1914 in Antwerpen gereconstrueer. De nieuwe brug zal toekolisch heden, verleden to worst met elkar verbinden, en wordt feestelijk geopend op 5 oktor 2014 kijgen 3 , 4 n 5 oktober 2014 krijgen meer dan de pon de pontonbrug over de Schelde overte steken.Zezullen inde voetsporen treden van het Belgische leger, maar ook van de 100.000 chentingen die honderd jaar zich lieten.

$\diamond$ Van 3 tot 5 oktober 2014

$\diamond$ Steenplein, 2000 Antwerpen.

www.antwerpen14-18.be

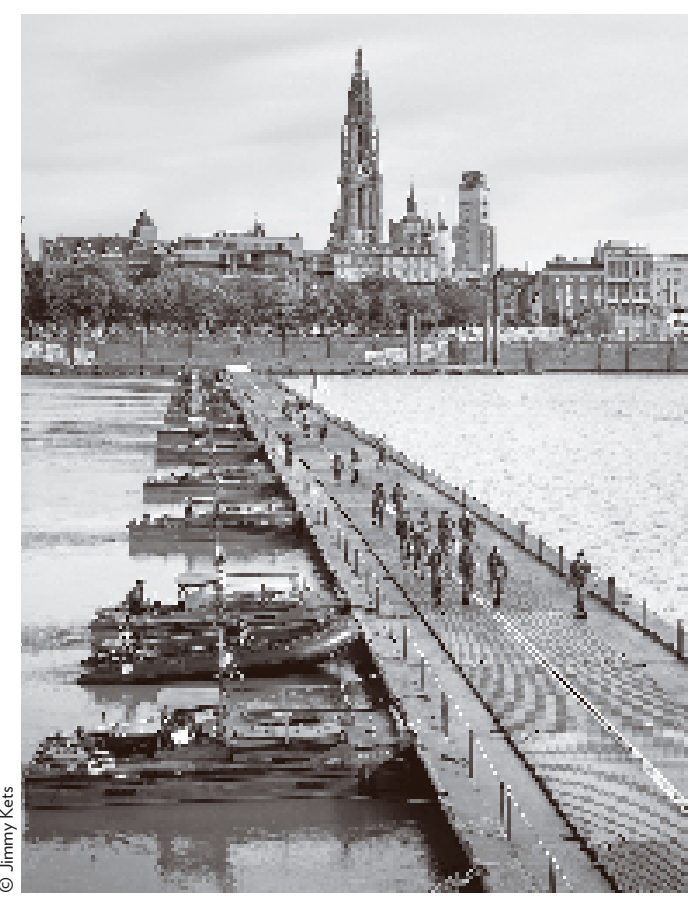

HEROPENING/

TENTOONSTELLING

\section{De IJzerslag}

Sinds 1 maart 2014 is het Museum aan de IJzer weer open voor het grote publiek. De vernieuwde museale invulling legt de focus op de Belgisch-Duitse confrontatie ijdens de Eerste Wereldoorlog en de chat 'Wat lijft van lopt loopt een tentoonstelling over de IJzerslag, die het ende betekende ber vin oopgravenoorlog. loopgravenoorlog.

$\diamond$ Van 1 oktober 2014 tot 30 november 2018.

$\rightarrow$ Museum aan de IJzer, IJzerdijk 49, 8600 Diksmuide

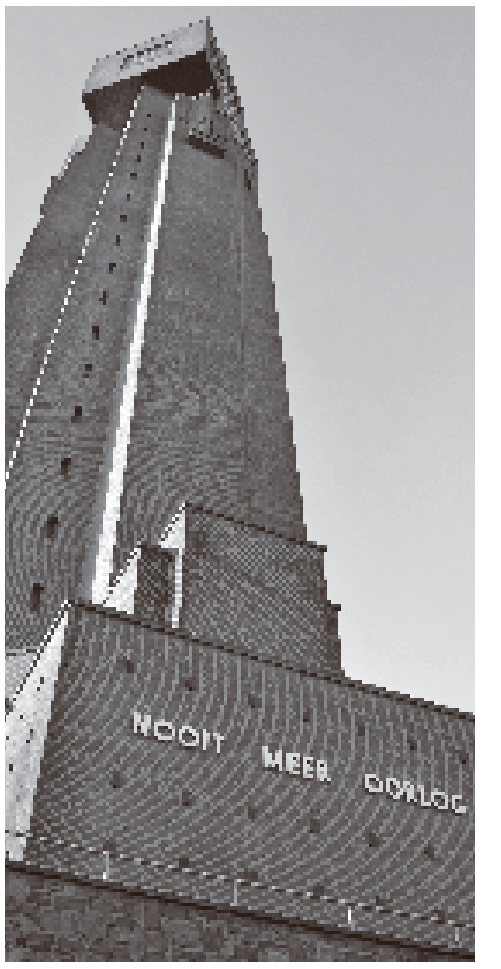

TENTOONSTELLING

De verschrikkingen van de oorlog, 1800-2014

De tentoonstelling toont een ijke verzameling afbeeldinge die voortkomen uit de desillusi he nonger van het begin van Centraal starn en twintigtal Centraal staan een twintigta ontisce war oorlogen en de oolog in Vietnam.

$\diamond$ Tot 30 oktober 2014

$\triangle$ Musée du Louvre-Lens,

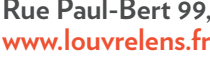

www.cheminsdememoire-
nordpasdecalais.fr

TENTOONSTELLING

\section{4-18, OORLOG IN BEELD/ \\ BRUGGEIN OORLOG}

De stad herdenkt de 'Groote Oorlog' met verschillende tentoonstellingen. Twee fototentoonstellingen onder curatorschap van Carl De Keyzer en David Van Reybrouck tonen zowe Grote Orlog als hedendags werk ur cor fotoagentschap. Daarnaast werkte Sophie De Schaepdrijver (vgl. het

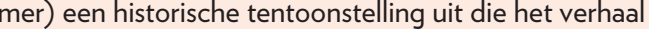
brengt van het bezette Brugge, vanaf de mobilisatie van juli 2014 tot en met de naoorlogse herdenkingen van 1919-1920.

$\diamond$ Stadshallen, Markt 7, 8000 Brugge.

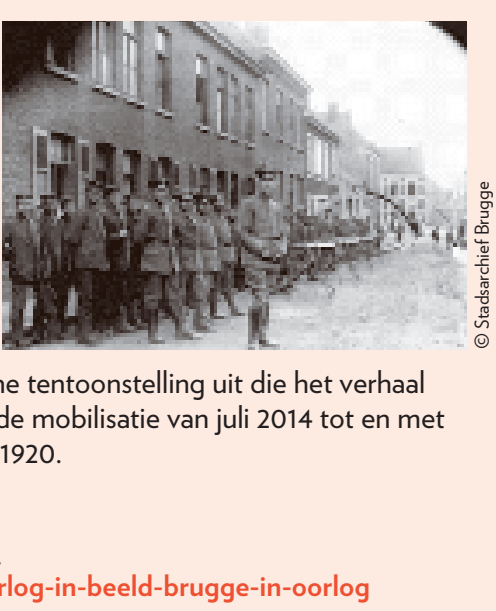

\section{NOVEMBER}

CONFERENCE

\section{Entrer en guerre \\ (Going to war)}

Université Paris 7 and the International Research Centre of the Great War in Péronne have come together to organize an interdisWhinary conference on the First

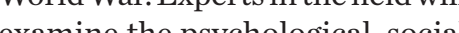
.

$\diamond$ 20-22 November 2014

Université Paris 7 Denis Didero Ue Thomas-Mann 5, 75013 Paris. examine the psychological, social 